Entry

\title{
Ionic Liquids in Drug Delivery
}

\author{
Sónia N. Pedro (D), Carmen S. R. Freire, Armando J. D. Silvestre (D) and Mara G. Freire *(D)
}

Department of Chemistry, CICECO-Aveiro Institute of Materials, University of Aveiro, 3810-193 Aveiro, Portugal; soniapedro@ua.pt (S.N.P.); cfreire@ua.pt (C.S.R.F.); armsil@ua.pt (A.J.D.S.)

* Correspondence: maragfreire@ua.pt

Definition: Ionic liquids (ILs) are molten salts composed of a large organic cation and an organic/inorganic anion. Due to their ionic character, most ILs present advantageous properties over conventional solvents, such as negligible volatility at atmospheric conditions and high thermal and chemical stabilities. The wide variety of IL anion-cation combinations allows these solvents to be designed to display a strong solvation ability for a myriad of active pharmaceutical ingredients (APIs) and (bio)polymers. Given these properties, ILs have been used as solvents and as formulation components in different areas of drug delivery, as well as novel liquid forms of APIs (API-ILs) applied in different stages of development of novel drug delivery systems. Furthermore, their combination with polymers and biopolymers has enabled the design of drug delivery systems for new therapeutic routes of administration.

Keywords: active pharmaceutical ingredients; drug delivery; formulations; ionic liquids; permeation enhancers; stimuli-responsive systems

Citation: Pedro, S.N.; Freire, C.S.R.; Silvestre, A.J.D.; Freire, M.G. Ionic Liquids in Drug Delivery. Encyclopedia 2021, 1, 324-339. https://doi.org/10.3390/ encyclopedia1020027

Academic Editor: Jose L. Arias

Received: 23 February 2021

Accepted: 25 March 2021

Published: 1 April 2021

Publisher's Note: MDPI stays neutral with regard to jurisdictional claims in published maps and institutional affiliations.

Copyright: (c) 2021 by the authors. Licensee MDPI, Basel, Switzerland. This article is an open access article distributed under the terms and conditions of the Creative Commons Attribution (CC BY) license (https:// creativecommons.org/licenses/by/ $4.0 /)$.

\section{Introduction}

Delivering active pharmaceutical ingredients (APIs) at a controlled rate or offering targeted delivery are appealing therapeutic options [1]. Since the majority of APIs in the market and under development are low-water soluble, developing drug delivery systems that can guarantee high efficiency and bioavailability is a challenging issue [2,3]. Drug delivery systems can be defined as formulations or devices that enable the introduction of an API into the human body, while improving their efficacy and safety by controlling the rate, time and place of release [4]. Since the 1950s, drug delivery systems have experienced continuous evolution [5]. However, in recent years, the study of nanoparticles, such as micelles, liposomes, dendrimers, nanocapsules, and nanospheres, among others, opened a window of opportunity to develop novel effective therapies and reduce adverse sideeffects. For instance, a number of successful nanoparticle-based systems has been already approved by the U. S. Food and Drug Administration (FDA), such as Doxil (liposomal doxorubicin) [6] and AmBisome (liposomal amphotericin B) [7].

In drug formulation and administration, the use of volatile organic solvents is commonly applied to improve the solubility of APIs for drug research or to test in vivo effects on biological targets. Nonetheless, the use of large amounts of organic solvents represents major health and environmental concerns [8]. The identification of the correct solvents or co-solvents needs to be well considered for the intended route of administration [9], in which water should be the preferred choice, and the addition of excipients such as surfactants, lipids, or polymers may afford higher solubility and stability of target APIs. Excipients are inert pharmaceutical ingredients that are used in product formulations. Each excipient presents a specific application with impact on the final efficacy of the dosage form, such as $\mathrm{pH}$ adjustment agents, preservatives or vehicles. The overall properties of the final dosage form are mostly dependent on the excipients chosen, the concentration selected, and the interaction between these components and the API. Thus, selecting a solvent/mixture that can serve the purpose of a vehicle and can enhance the solubility, 
permeation, stability, and bioavailability of the drug, while being biocompatible, is an appealing alternative to be pursued.

Despite the extensive research on "greener" alternative solvents to drug solubilization and delivery, the approval and implementation of such alternatives is still scattered [10-12]. In 1914, Paul Walden reported the possibility of having salts that are liquid at room temperature, being nowadays known as ionic liquids (ILs). ILs are molten salts composed of a large organic cation and an organic/inorganic anion, and that can be seen as promising alternative solvents to be investigated in drugs solubilization and delivery fields. The large dimensions of their ions lead to charge dispersion, which makes the formation of a regular crystalline structure difficult $[13,14]$. ILs, if properly designed, display a set of unique features, such as a high thermal and chemical stability and a strong solvation ability for a wide variety of compounds, from which APIs and (bio)polymers can be highlighted [15]. This versatility additionally discloses high potential in several areas of drug delivery. The adequate selection of anions and cations allows the creation of ILs with enhanced solvation ability for APIs or the synthesis of ILs with specific biological activities [16]. In the first approach, ILs have been used as solvents and co-solvents of APIs, in which enhancements in the order $11 \times 10^{6}$-fold have been reported for paclitaxel [17]. On the other hand, promising results on antioxidant [18,19], anti-tumoral [20,21], and antimicrobial activities [22-26] displayed by ILs have been disclosed. Furthermore, the inclusion of APIs as cations and/or anions in the IL composition also enables the conversion of a solid API into a liquid form (API-ILs). This strategy overcomes the polymorphism concerns, provides enhanced solubility and ideally improves therapeutic efficacy [2,27].

Given the flexibility in the design of API-ILs, it is also possible to improve the API's permeation through biological membranes [28]. This is not only possible for the combination of APIs with permeation enhancers, but also for the use of ILs with surfactant activity as novel excipients in formulations [29]. Given this possibility, ILs have been studied as different formulation components of microemulsions attempting to develop more effective delivery systems.

To improve drug delivery, the design of novel systems with polymers and biopolymers has also been attempted by using ILs as media for polymerization processes, for polymer processing, and offering the opportunity for the in situ functionalization [30,31]. Due to the versatility of IL applications, the design of IL and polymer-based nanosystems can also be envisaged [32], as well as the stimuli-responsive delivery of APIs [33].

Due to the advantageous properties of ILs, they have been extensively investigated as different components in drug delivery systems, summarized in Figure 1, attempting to unveil novel and more effective options.

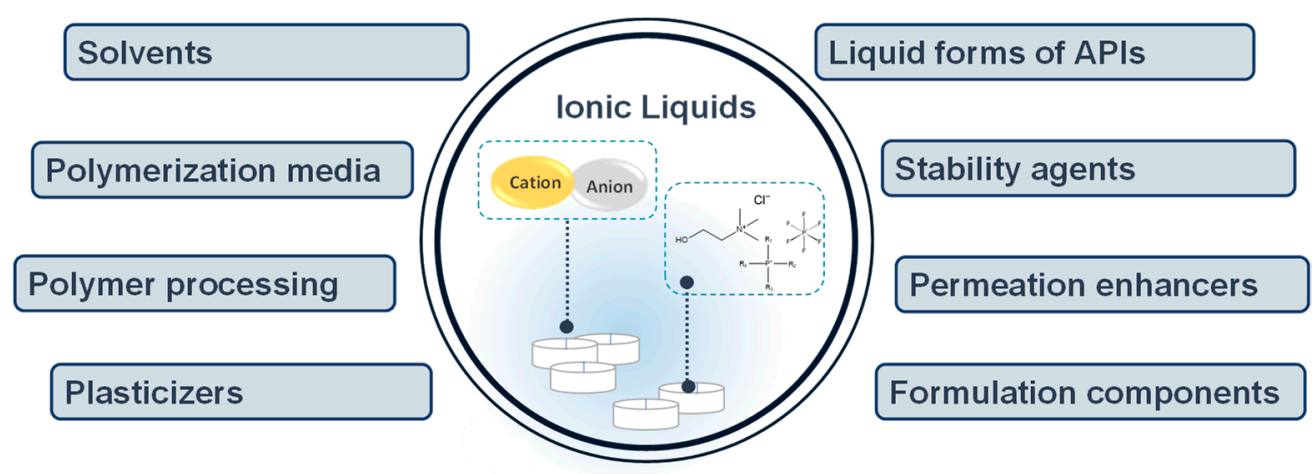

Figure 1. Applications of ionic liquids (ILs) in drug delivery systems design and development.

\section{Applications of Ionic Liquids in Drug Delivery}

\subsection{ILs as Novel Solvents of APIs}

APIs displaying low-water solubility are commonly solubilized by the use of organic solvents as solvents or co-solvents (e.g., ethanol or dimethyl sulfoxide) in pharmaceutical 
formulations [34]. In this context, and in addition to their use as surfactants discussed above that might also improve the API solubilization, ILs have been investigated as promising solvents, co-solvents and hydrotropes to increase the aqueous solubility of APIs [35]. The use of ILs as alternative solvents to this purpose was first introduced by Jaitely et al. [36], in 2008, when using imidazolium-based ILs to solubilize potassium penicillin V, dexamethasone, dehydroepiandrosterone and progesterone. After this, several studies reported solubility enhancements by several orders of magnitude for antifungal [35,37,38], analgesic [35], non-steroidal anti-inflammatory [39,40], and anti-cancer [17,41] drugs when using ILs and compared to their water solubility.

The proper selection of the ILs' anions and cations has proven to dictate the solubilization mechanism of low water-soluble APIs and the IL solvation mechanism/ability. An adequate hydrophilic-lipophilic balance between the IL cations and anions enables the design of both drug delivery systems and solubilization agents to improve the aqueous solubility of APIs from different pharmacological classes [38]. The solubilization of these APIs is driven by cosolvency, hydrotropy and micellization mechanisms, enabling the solubility enhancements summarized in Table 1.

Table 1. Solubility enhancement of different active pharmaceutical ingredients (APIs) provided by ILs in comparison with their water solubility.

\begin{tabular}{|c|c|c|c|c|}
\hline API & Water Solubility & IL & Solubility & Reference \\
\hline Amphotericin B & $2.0 \times 10^{-4 a}$ & $\begin{array}{c}{\left[\mathrm{C}_{2} \mathrm{C}_{1} \mathrm{im}\right]\left[\mathrm{CH}_{3} \mathrm{CO}_{2}\right]} \\
{\left[\mathrm{C}_{4} \mathrm{NH}_{3}\right]\left[\mathrm{CH}_{3} \mathrm{CO}_{2}\right]} \\
{\left[\mathrm{C}_{6} \mathrm{NH}_{3}\right]\left[\mathrm{CH}_{3} \mathrm{CO}_{2}\right]} \\
{\left[\mathrm{C}_{8} \mathrm{NH}_{3}\right]\left[\mathrm{CH}_{3} \mathrm{CO}_{2}\right]} \\
{\left[\mathrm{C}_{4} \mathrm{NH}_{3}\right][\text { Oleate] }} \\
{\left[\mathrm{C}_{6} \mathrm{NH}_{3}\right][\text { Oleate] }} \\
{\left[\mathrm{C}_{8} \mathrm{NH}_{3}\right][\text { Oleate }]} \\
\end{array}$ & $\begin{array}{l}85^{\mathrm{a}} \\
30^{\mathrm{a}} \\
30^{\mathrm{a}} \\
20^{\mathrm{a}} \\
<5^{\mathrm{a}} \\
<5^{\mathrm{a}} \\
<5^{\mathrm{a}}\end{array}$ & [38] \\
\hline Albendazole & $0.0020^{b}$ & $\begin{array}{l}{\left[\mathrm{C}_{4} \mathrm{C}_{1} \mathrm{im}\right]\left[\mathrm{BF}_{4}\right]} \\
{\left[\mathrm{C}_{6} \mathrm{C}_{1} \mathrm{im}\right]\left[\mathrm{BF}_{4}\right]}\end{array}$ & $\begin{array}{l}1.49^{b} \\
2.97^{b}\end{array}$ & [35] \\
\hline Danazol & $0.00030^{b}$ & $\begin{array}{c}{\left[\mathrm{C}_{4} \mathrm{C}_{1} \mathrm{im}\right]\left[\mathrm{BF}_{4}\right]} \\
{\left[\mathrm{C}_{8} \mathrm{C}_{1} \mathrm{im}\right]\left[\mathrm{BF}_{4}\right]} \\
{\left[\mathrm{C}_{4} \mathrm{C}_{1} \mathrm{im}\right]\left[\mathrm{PF}_{6}\right]} \\
{\left[\mathrm{C}_{8} \mathrm{C}_{1} \mathrm{im}\right]\left[\mathrm{PF}_{6}\right]} \\
{\left[\mathrm{C}_{6} \mathrm{C}_{6} \mathrm{OCOpy}\right]\left[\mathrm{N}(\mathrm{CN})_{2}\right]} \\
{\left[\mathrm{C}_{6} \mathrm{C}_{6} \mathrm{OCOpy}\right]\left[\mathrm{NTf}_{2}\right]}\end{array}$ & $\begin{array}{c}18.9^{\mathrm{b}} \\
>59^{\mathrm{b}} \\
11.9^{\mathrm{b}} \\
35^{\mathrm{b}} \\
>90^{\mathrm{c}} \\
25^{\mathrm{c}}\end{array}$ & [35] \\
\hline Itraconazole & $1.0 \times 10^{-6 a}$ & 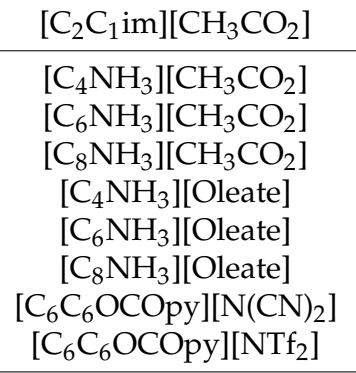 & $\begin{array}{l}<5^{\mathrm{a}} \\
<5^{\mathrm{a}} \\
<5^{\mathrm{a}} \\
<5^{\mathrm{a}} \\
<5^{\mathrm{a}} \\
<5^{\mathrm{a}} \\
<5^{\mathrm{a}} \\
40^{\mathrm{c}} \\
8^{\mathrm{c}}\end{array}$ & {$[38]$} \\
\hline Etodolac & Insoluble & {$\left[\mathrm{C}_{4} \mathrm{C}_{1} \mathrm{im}\right]\left[\mathrm{PF}_{6}\right]$} & $374.33^{a *}$ & [39] \\
\hline Acetaminophen & $98.8^{b}$ & $\begin{array}{l}{\left[\mathrm{C}_{4} \mathrm{C}_{1} \mathrm{im}\right]\left[\mathrm{BF}_{4}\right]} \\
{\left[\mathrm{C}_{8} \mathrm{C}_{1} \mathrm{im}\right]\left[\mathrm{BF}_{4}\right]} \\
{\left[\mathrm{C}_{4} \mathrm{C}_{1} \mathrm{im}\right]\left[\mathrm{PF}_{6}\right]} \\
{\left[\mathrm{C}_{8} \mathrm{C}_{1} \mathrm{im}\right]\left[\mathrm{PF}_{6}\right]}\end{array}$ & $\begin{array}{l}>132^{b} \\
126^{b} \\
52^{b} \\
10^{b}\end{array}$ & [35] \\
\hline Ibuprofen & $0.124^{a}$ & $\begin{array}{l}{\left[\mathrm{C}_{4} \mathrm{C}_{1} \mathrm{im}\right]\left[\mathrm{PF}_{6}\right]} \\
{\left[\mathrm{C}_{6} \mathrm{C}_{1} \mathrm{im}\right]\left[\mathrm{PF}_{6}\right]}\end{array}$ & $\begin{array}{c}6.95^{\mathrm{a}} \\
26.38^{\mathrm{a}}\end{array}$ & [40] \\
\hline 5-Fluorouracil & $12.21^{\mathrm{a} *}$ & {$\left[\mathrm{C}_{4} \mathrm{C}_{1} \mathrm{im}\right] \mathrm{Br}$} & $31.19^{a *}$ & {$[41]$} \\
\hline
\end{tabular}


Table 1. Cont.

\begin{tabular}{|c|c|c|c|c|}
\hline API & Water Solubility & IL & Solubility & Reference \\
\hline Paclitaxel & $<4.0 \times 10^{-6 \mathrm{a}}$ & $\begin{array}{c}\text { [Ch][Gly] } \\
\text { [Ch][Ala] } \\
\text { [Ch][Pro] } \\
\text { [Ch][Phe] } \\
\text { [Ch][Ile] } \\
\text { [Ch][Ser] } \\
\text { [Ch][Leu] }\end{array}$ & $\begin{array}{l}22.34^{\mathrm{a}} \\
18.52^{\mathrm{a}} \\
16.16^{\mathrm{a}} \\
14.15^{\mathrm{a}} \\
9.39^{\mathrm{a}} \\
7.32^{\mathrm{a}} \\
6.61^{\mathrm{a}}\end{array}$ & [17] \\
\hline
\end{tabular}

${ }^{\mathrm{a}}: \mathrm{mg} \cdot \mathrm{mL}^{-1} ;{ }^{\mathrm{b}}: \mathrm{mmol} \cdot \mathrm{L}^{-1} ;{ }^{\mathrm{c}}: \mathrm{mg} \cdot \mathrm{g}^{-1}$. ${ }^{*}$ Solubility determined at body's temperature $\left(34-38^{\circ} \mathrm{C}\right)$. If not specified, the reported solubilities at $21-30{ }^{\circ} \mathrm{C}$.

The solubility of drugs like amphotericin B, itraconazole, paclitaxel, or etodolac, which are sparingly soluble in water, can be enhanced by several orders of magnitude (up to $5.6 \times 10^{6}$-fold; cf. Table 1) by using ILs for this purpose. Although imidazolium-based ILs have been the most investigated ILs for this purpose, the application of cholinium-based ones promote the search for more benign alternatives. Further from their application to improve the solubility, the stability of these APIs in IL media, as well as the bioavailability of the API in IL-based formulations, needs to be more extensively investigated.

\subsection{Liquid Forms of APIs}

Low water-soluble APIs present bioavailability concerns that negatively impact the final therapeutic efficacy; consequently, these APIs usually fail in the later stages of development or comprise adverse effects related with their deposition [42-44]. On the other hand, solid forms of APIs can present different bioavailability profiles associated with the occurrence of different polymorphs, which might constitute an issue if the inadequate polymorph, i.e., more toxic, is administrated [45]. Therefore, the development of liquid forms of APIs can be an advantageous strategy to avoid such concerns. Furthermore, in contrast with solid forms of APIs, liquids can surpass the energy barrier associated with the enthalpy of fusion, displaying higher solubility in water and thus a higher therapeutic response [46].

ILs have shown promising applicability to improve physical stability while increasing the drug's solubility and permeation. The adequate selection of the IL's components also allows the use of APIs as either anions or cations, resulting in liquid forms of drugs (API-ILs). API-ILs were first introduced in 2007, by Rogers et al. [47], with the synthesis of ranitidinium docusate ([Ran][Doc]), which is liquid at room temperature and shows improved API absorption. This discovery opened the possibility of obtaining new liquid forms of APIs with specific physicochemical and biological properties, and/or liquids with dual pharmacological action $[47,48]$. These novel ILs can also be obtained by application of the prodrug strategy to one of the ions of the API-IL, i.e., comprising a biologically inert compound that undergoes enzymatic conversion into the active species of the API-IL, or through the use of oligomeric ions by simply changing the stoichiometry or introducing the free acid/base of the conjugate base/acid within the salt formulation [28,49].

API-ILs belonging to different pharmacological classes have been reported, including with anesthetic [16,50], anti-inflammatory [51-53], analgesic [50,54], and antimicrobial [52] activities. When considering API-ILs with double therapeutic action, different melting temperatures, solubilities, bioavailability profiles and stabilities are observed for the two APIs in comparison to the precursors. Some of the dual API-ILs reported so far are summarized in Table 2, being given the respective pharmacological action. 
Table 2. Pharmacological activity of liquid forms of API-ILs, biological activity and application.

\begin{tabular}{|c|c|c|c|c|}
\hline API-IL & Cation Activity & Anion Activity & Application & Ref \\
\hline Ranitidinium docusate & $\begin{array}{l}\text { Decreases acid } \\
\text { stomach production }\end{array}$ & Laxative & $\begin{array}{c}\text { Prevents drug } \\
\text { polymorphism } \\
\text { Increases API absorption }\end{array}$ & [47] \\
\hline Procainium salicylate & Local anesthetic & Antimicrobial & Enhanced solubility & [50] \\
\hline Tramadolium salicylate & Analgesic & Antimicrobial & Enhanced solubility & [50] \\
\hline Lidocainium etodolac & Anesthetic & Anti-inflammatory & $\begin{array}{c}\text { Enhanced skin } \\
\text { Permeation (In vivo testing) }\end{array}$ & [55] \\
\hline $\begin{array}{l}\text { Lidocainium } \\
\text { ibuprofenate }\end{array}$ & Anesthetic & Anti-inflammatory & $\begin{array}{l}\text { Supported ILs } \\
\text { Fast release profile in GI } \\
\text { environment }\end{array}$ & [56] \\
\hline $\begin{array}{l}\text { Bromohexinium } \\
\text { ibuprofenate }\end{array}$ & Mucolytic & Anti-inflammatory & $\begin{array}{l}\text { Enhanced membrane } \\
\text { permeation }\end{array}$ & [57] \\
\hline $\begin{array}{l}\text { Benzalkonium } \\
\text { salicylate }\end{array}$ & Antimicrobial & Antimicrobial & $\begin{array}{c}\text { Enhanced solubility } \\
\text { Binding affinity to HSA }\end{array}$ & [58] \\
\hline Tetracycline docusate & Antimicrobial & Laxative & Higher partition coefficient & [59] \\
\hline
\end{tabular}

The combination of lidocaine and etodolac, both very low-water soluble drugs, and the respective conversion into the form of lidocainium etodolac, results in higher water solubility when compared with the individualized APIs, with an increase of $>90$-fold for etodolac and 2-fold for lidocaine [55]. Such behavior has enabled the development of the patch Etoreat, by IL Pharma Inc. (MEDRx, Kagawa, Japan), for the treatment of ankle sprains and low back pain [60]. This is one of the few API-IL systems that has reached clinical trials. However, the subsequent development of the patch has been suspended due to the lack of statistically significant results between Etoreat and placebo administration. The lack of clinically effective API-IL applications boosted the research for more effective IL combinations for this purpose for different therapeutic purposes.

\subsection{ILs as Permeation Enhancers and Microemulsion Components for Drug Delivery}

Given the flexibility of the design of the API-IL approach, the improvement of the APIs' permeation through biological membranes can be accomplished through the combination of APIs with permeation enhancers $[27,28]$. This strategy was first investigated by Megwa et al. [61], who combined the salicylate anion with alkylammonium and quaternary ammonium cations to improve the skin permeation of the API. After this pioneering work, other studies attempted to improve the permeation of salicylates across membranes, being reported as new salicylate-based ILs [62] and ILs with derivatives of poly(ethylene glycol) [63]. The selection of more biocompatible cations, such as amino acids, has been also considered for this purpose [64]. The API-IL prolinium ethylester ibuprofenate allowed an enhancement of the permeation of the API up to 10 times across pig skin when compared to its parent solubilized in PBS/ethanol solution, without significant toxicity to fibroblast cells [64].

In addition to API-IL formulations, ILs can be designed to present tunable lipophilicity/hydrophilicity character, and to not only increase solubility in aqueous media, but also to improve permeation through biological membranes [38]. These ILs (so called surface-active ionic liquids (SAILs)) have been studied as novel drug carriers and their performance has been compared to conventional surfactants, with the first exhibiting superior ability [65]. Attempting to explain the mechanisms by which these ILs enable a superior drug delivery, several studies on the interaction between IL and biological membranes were conducted $[66,67]$. Using neutron scattering, it was verified that ILs might induce a shrinking thickness of the bilayer, whereas the accumulation of the ILs' cations between the polar heads and hydrocarbon tails of lipids occurs along with changes in the lipidic bilayer composition [68]. Later, through fluorescence imaging and light and X-ray scattering techniques, the insertion of amphiphilic ILs in the lipid bilayer was demonstrated [66]. The 
possible disruption of the membrane is dependent on the hydrophobicity of the alkyl chain of the IL cation and anion. Following these elucidations, ILs have been studied regarding their ability to fluidize cell membranes; imidazolium-based ILs with hydrophobic character destabilize membranes and create channels through biological membranes for APIs transportation, whereas hydrophilic ILs display the opposite behavior [69]. Therefore, by careful adjustment of the IL's ions, its composition and the therapeutic target, it is possible to improve the transdermal delivery of several APIs without compromising the membrane integrity (in accordance with the IL hydrophobic/hydrophilic balance) [70].

Overall, the possibility of creating micelles using SAILs has been investigated to design intravenous, topical and transdermal delivery [71,72]. In the former delivery route, ILs have been particularly applied for the development of microemulsions. Microemulsions are thermodynamically stable colloidal mixtures of two immiscible liquids (i.e., water and oil) stabilized by surfactant molecules [73]. ILs proved to be promising alternatives to these components, being able to replace oil, water, and surfactant phases (Figure 2), improving the delivery of APIs across biological membranes [74,75].
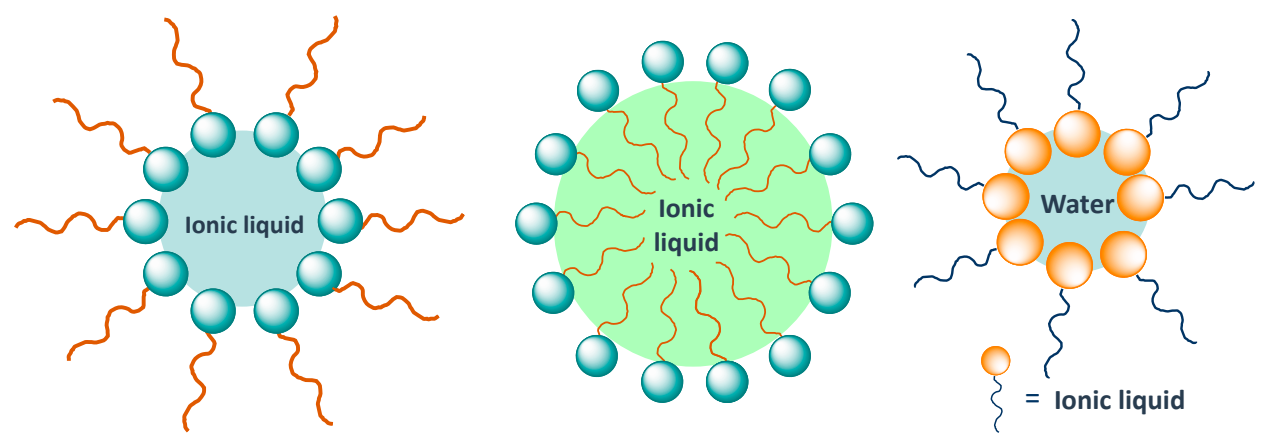

Figure 2. Schematic representation of the use of ILs as components in water, oil and surfactant phases (from left to right) in microemulsions.

\subsection{ILs as Novel Solvents of (Bio)Polymers}

Due to ILs' unique properties and the wide variety of intermolecular interactions afforded, these solvents have proven to be also adequate solvents for biopolymers dissolution, allowing the substitution of the use of organic solvents in this field. In this sense, the dissolution of proteins [76,77], and more extensively polysaccharides (e.g., cellulose [78], chitosan [79,80], chitin [81], or guar gum [82]), has been reported using mostly imidazoliumbased ILs, as summarized in Table 3. Despite the promising results reported, biopolymers' dissolution is usually performed at moderately high temperatures; thus, to prevent the biopolymers' decomposition or incomplete dissolution, the dissolution conditions should be carefully evaluated and the IL properly designed for this purpose.

The solvation mechanism for biopolymers considered in Table 3 differs according to the structure of the biopolymer and the IL. By using 1-butyl-3-methylimidazolium chloride $\left(\left[\mathrm{C}_{4} \mathrm{C}_{1} \mathrm{im}\right] \mathrm{Cl}\right)$, the high cellulose dissolution ability was attributed to strong hydrogenbonding between the carbohydrate hydroxyl protons of the biopolymer and the IL chloride ions [83]. On the other hand, chitin dissolution in ILs seems to be affected by the degree of acetylation, crystallinity and molecular weight of chitin, as well as by the IL anion nature [84]. Chitin is easily dissolved when presenting low degrees of acetylation, low crystallinity and low molecular weight. The use of ILs also represent a main advantage in the possibility to dissolve and extract the intended biopolymer from raw biomass, without requiring additional steps of purification. A major example of this possibility is the extraction of chitin from crustacean shells [85]. One particular IL, 1-ethyl-3-methylimidazolium acetate $\left(\left[\mathrm{C}_{2} \mathrm{C}_{1} \mathrm{im}\right]\left[\mathrm{CH}_{3} \mathrm{CO}_{2}\right]\right)$, has been applied for the complete dissolution of raw shrimp shells. The use of this alternative solvent leads to the recovery of a high purity $(>80 \%)$, high molecular weight chitin powder $[85,86]$. Using this approach, chitin-based systems, like fibers, can be directly spun from the extract solution. The successful results 
for this process allowed the creation of the first facility (Mari Signum) that uses an IL-based process for chitin extraction on a production scale, aiming to generate sufficient supplies of high-quality chitin and be a competitive alternative in this market area [87].

Further studies with chitosan showed an almost linear increase in the biopolymer solubility with the increase in the hydrogen bond-accepting ability of the IL [88]. Imidazoliumbased anions seem to play a major role in the dissolution of chitosan, possibly due to the disruption of its native hydrogen bonds. Overall, the gathered fundamental knowledge has enabled the application of ILs in the dissolution of several biopolymers and polymers simultaneously, leading to new directions of materials and delivery systems. One example is the possibility of preparing micro and nanoparticles by suspension polymerization reactions, where the average particle size can be tuned by adjusting the concentration and the alkyl chain length of ILs [89], or the possibility of obtaining homogenous biopolymer blends in a faster and easy process $[90,91]$.

Table 3. Biopolymer solubility in ILs and respective conditions.

\begin{tabular}{|c|c|c|c|c|}
\hline Biopolymers & IL & Solubility (wt\%) & Dissolution Conditions & Ref \\
\hline \multirow{2}{*}{ Silk fibroin } & $\begin{array}{c}{\left[\mathrm{C}_{4} \mathrm{C}_{1} \mathrm{im}\right]\left[\mathrm{CH}_{3} \mathrm{CO}_{2}\right]} \\
{\left[\mathrm{C}_{4} \mathrm{C}_{1} \mathrm{im}\right] \mathrm{Cl}}\end{array}$ & $\begin{array}{l}10 \\
13\end{array}$ & $\begin{array}{c}95^{\circ} \mathrm{C}, 6 \mathrm{~h} \\
100^{\circ} \mathrm{C}\end{array}$ & [76] \\
\hline & {$\left[\mathrm{C}_{2} \mathrm{C}_{1} \mathrm{im}\right] \mathrm{Cl}$} & 23 & $100^{\circ} \mathrm{C}$ & [77] \\
\hline Cellulose & {$\left[\mathrm{C}_{2} \mathrm{C}_{1} \mathrm{im}\right]\left[\mathrm{CH}_{3} \mathrm{CO}_{2}\right]$} & 23 & $90^{\circ} \mathrm{C}, 2 \mathrm{~h}$ & [78] \\
\hline Chitin & {$\left[\left(\mathrm{CH}_{2} \mathrm{CH}=\mathrm{C}_{2}\right) \mathrm{C}_{1} \mathrm{im}\right] \mathrm{Br}$} & 4.8 & $100^{\circ} \mathrm{C}, 48 \mathrm{~h}$ & [81] \\
\hline \multirow{4}{*}{ Chitosan } & {$\left[\left(\mathrm{CH}_{2} \mathrm{CH}=\mathrm{C}_{2}\right) \mathrm{C}_{1} \mathrm{im}\right] \mathrm{Cl}$} & 3 & $100{ }^{\circ} \mathrm{C}, 30 \mathrm{~min}$ & [92] \\
\hline & {$\left[\mathrm{C}_{4} \mathrm{C}_{1} \mathrm{im}\right] \mathrm{Cl}$} & $0.2-0.8$ & $70-110^{\circ} \mathrm{C}, 2 \mathrm{~h}$ & [79] \\
\hline & {$\left[\mathrm{PSC}_{1} \mathrm{im}\right]\left[\mathrm{CH}_{3} \mathrm{CO}_{2}\right]$} & 1 & $\begin{array}{l}30^{\circ} \mathrm{C}, 35 \mathrm{~min} \text { using } 5 \% \\
w / w \text { of IL aqueous solution }\end{array}$ & \multirow{2}{*}[80]{} \\
\hline & {$\left[\mathrm{PSC}_{4} \mathrm{im}\right]\left[\mathrm{CH}_{3} \mathrm{CO}_{2}\right]$} & 1 & $\begin{array}{c}30^{\circ} \mathrm{C}, 37 \text { min using } 5 \% \\
w / w \text { of IL aqueous solution }\end{array}$ & \\
\hline Guar gum & {$\left[\mathrm{C}_{4} \mathrm{C}_{1} \mathrm{im}\right] \mathrm{Cl}$} & 10 & $80-100{ }^{\circ} \mathrm{C}, 1 \mathrm{~h}$ & [82] \\
\hline
\end{tabular}

In addition to the use of ILs in the solubilization of biopolymers, they can be used as well as solvents in the solubilization of synthetic polymers used in drug delivery. However, the occurrence of phase separation between ILs and some polymers and gel formation, as well as slow kinetics of dissolution, has mostly hindered the IL application in these polymers solubilization process. In fact, several studies can be found on liquid-liquid phase diagrams (phase separation) for polymer-IL binary mixtures $[93,94]$. One report on this topic, addressed by Noda et al. [95], describes the insolubility of poly(methyl methacrylate) (PMMA), polyacrylonitrile (PAN), and poly(ethylene glycol) (PEG) in 1-butylpyridinium chloride $\left(\left[\mathrm{C}_{4} \mathrm{py}\right] \mathrm{Cl}\right)$. However, some ILs have exhibited the ability to solubilize polyether, polystyrene, and polyvinyl-based polymers in different conditions, being summarized in Table 4. Even though there are numerous IL cation-anion combinations, studies on the solubility of these polymers have mainly addressed imidazolium-based ILs. Imidazoliumbased cations, such as $\left[\mathrm{C}_{2-8} \mathrm{C}_{1} \mathrm{im}\right]^{+}$and $\left[\mathrm{CH}=\mathrm{C}_{2} \mathrm{C}_{1} \mathrm{im}\right]^{+}$, have been studied in combination with different anions, namely, chloride, acetate, and several fluoride-based anions, such as tetrafluoroborate, hexafluorophosphate, bis(trifluoromethanesulfonyl)imide and trifluoromethanesulfonate [96-98] (chemical structures depicted in Figure 3; abbreviations description given in the end of the chapter). 
Table 4. Polymer solubility in IL media and respective temperature conditions.

\begin{tabular}{|c|c|c|c|c|}
\hline Polymer & IL & Solubility $(w / w \%)$ & $\mathrm{T}\left({ }^{\circ} \mathrm{C}\right)$ & Ref \\
\hline \multirow[b]{2}{*}{ Poly(ethylene glycol)(PEG) } & {$\left[\mathrm{C}_{4} \mathrm{C}_{1} \mathrm{im}\right]\left[\mathrm{BF}_{4}\right]$} & 3.55 & 25.0 & [96] \\
\hline & $\begin{array}{c}{\left[\mathrm{C}_{2} \mathrm{C}_{1} \mathrm{im}\right]\left[\mathrm{NTf}_{2}\right]} \\
{\left[\mathrm{C}_{4} \mathrm{C}_{1} \mathrm{im}\right]\left[\mathrm{NTf}_{2}\right]} \\
{\left[\mathrm{C}_{4} \mathrm{C}_{1} \mathrm{im}\right]\left[\mathrm{PF}_{6}\right]}\end{array}$ & 10 & $25-200$ & [97] \\
\hline Polypropylene glycol (PPG) & {$\left[\mathrm{C}_{4} \mathrm{C}_{1} \mathrm{im}\right]\left[\mathrm{NTf}_{2}\right]$} & 10 & 48.0 & [97] \\
\hline Poly(ethyl glycidyl ether) (PEGE) & $\begin{array}{c}{\left[\mathrm{C}_{2} \mathrm{C}_{1} \mathrm{im}\right]\left[\mathrm{NTF}_{2}\right]} \\
{\left[\mathrm{C}_{4} \mathrm{C}_{1} \mathrm{im}\right]\left[\mathrm{NTF}_{2}\right]} \\
{\left[\mathrm{C}_{4} \mathrm{C}_{1} \mathrm{im}\right]\left[\mathrm{PF}_{6}\right]} \\
{\left[\mathrm{C}_{2} \mathrm{C}_{1} \mathrm{im}\right]\left[\mathrm{CF}_{3} \mathrm{SO}_{3}\right]} \\
{\left[\mathrm{C}_{4} \mathrm{C}_{1} \mathrm{im}\right]\left[\mathrm{CF}_{3} \mathrm{SO}_{3}\right]} \\
{\left[\mathrm{C}_{4} \mathrm{C}_{1} \mathrm{im}_{3}\right]\left[\mathrm{BF}_{4}\right]} \\
{\left[\mathrm{C}_{8} \mathrm{C}_{1} \mathrm{im}\right]\left[\mathrm{PF}_{6}\right]}\end{array}$ & $\begin{array}{c}10 \\
\text { Insoluble } \\
\text { Insoluble } \\
10 \\
\end{array}$ & $\begin{array}{c}25-200 \\
67.0 \\
\end{array}$ & [97] \\
\hline \multirow[t]{2}{*}{ Poly(hydroxyethyl methacrylate) (PHEMA) } & $\begin{array}{c}{\left[\mathrm{C}_{4} \mathrm{py}\right]\left[\mathrm{BF}_{4}\right]} \\
{\left[\mathrm{C}_{2} \mathrm{C}_{1} \mathrm{im}\right]\left[\mathrm{BF}_{4}\right]}\end{array}$ & Soluble & 80.0 & [95] \\
\hline & {$\left[\mathrm{C}_{4} \mathrm{C}_{1} \mathrm{im}\right] \mathrm{Cl}$} & Soluble & 55.0 & [98] \\
\hline \multirow{3}{*}{ Poly(methyl methacrylate) (PMMA) } & {$\left[\mathrm{C}_{4} \mathrm{py}\right]\left[\mathrm{BF}_{4}\right]$} & \multirow[b]{2}{*}{ Insoluble } & & [95] \\
\hline & $\begin{array}{c}{\left[\mathrm{C}_{4} \mathrm{C}_{1} \mathrm{im}\right]\left[\mathrm{PF}_{6}\right]} \\
{\left[\mathrm{C}_{4} \mathrm{C}_{1} \mathrm{im}\right] \mathrm{Cl}} \\
\end{array}$ & & 55.0 & {$[98]$} \\
\hline & $\begin{array}{l}{\left[\mathrm{C}_{2} \mathrm{C}_{1} \mathrm{im}\right]\left[\mathrm{NTf}_{2}\right]} \\
{\left[\mathrm{C}_{4} \mathrm{C}_{1} \mathrm{im}\right]\left[\mathrm{NTf}_{2}\right]} \\
{\left[\mathrm{C}_{8} \mathrm{C}_{1} \text { im }\right]\left[\mathrm{NTf}_{2}\right]}\end{array}$ & 0.1 & 25.0 & [100] \\
\hline Polyacrylonitrile (PAN) & $\begin{array}{c}{\left[\mathrm{C}_{4} \mathrm{py}\right]\left[\mathrm{BF}_{4}\right]} \\
{\left[\mathrm{C}_{4} \mathrm{C}_{1} \mathrm{im}\right]\left[\mathrm{BF}_{4}\right]}\end{array}$ & Insoluble & 80.0 & [95] \\
\hline Poly(vinyl alcohol) (PVA) & $\begin{array}{c}{\left[\mathrm{C}_{4} \mathrm{C}_{1} \mathrm{im}\right][\mathrm{HCOO}]} \\
{\left[\left(\mathrm{CH}_{2} \mathrm{CH}=\mathrm{C}_{2}\right) \mathrm{C}_{1} \mathrm{im}\right] \mathrm{Cl}}\end{array}$ & $\begin{array}{c}0.03 \\
\text { Insoluble }\end{array}$ & $\begin{array}{l}25.0 \\
50.0\end{array}$ & \multirow{2}{*}{ [99] } \\
\hline Poly(styrene sulfonate) (PSS) & $\begin{array}{c}{\left[\mathrm{C}_{4} \mathrm{C}_{1} \mathrm{im}\right][\mathrm{HCOO}]} \\
{\left[\left(\mathrm{CH}_{2} \mathrm{CH}=\mathrm{C}_{2}\right) \mathrm{C}_{1} \mathrm{im}\right] \mathrm{Cl}}\end{array}$ & $\begin{array}{l}0.026 \\
0.026\end{array}$ & $\begin{array}{l}25.0 \\
50.0\end{array}$ & \\
\hline
\end{tabular}

\section{Cations}

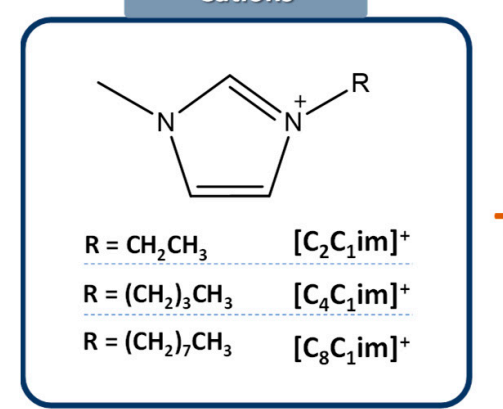

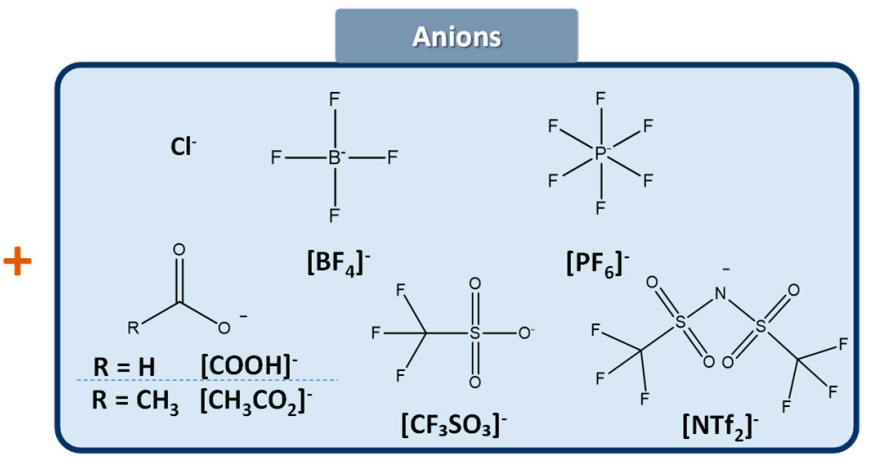

$\left[\mathrm{NTf}_{2}\right]^{-}$

Figure 3. Common IL cations and anions applied in the solubilization of synthetic polymers.

In general, it seems that ILs present a higher ability to solubilize more hydrophilic polymers rather than hydrophobic ones. Hydrophilic domains of polymers present a higher affinity towards the polar groups of ILs, favoring the solubilization process, as exemplified by Chen et al. [99] for polyvinyl alcohol (PVA). Contrarily, hydrophobic polymers are more prone to interact with the non-polar domains of ILs (alkyl chains), resulting in the polymer's aggregation [99].

The study of ILs on biopolymer dissolution and processing allowed an establishment of a correlation between cellulose solubility and the hydrogen bond-accepting ability of ILs [101]. ILs' anions with a higher ability to accept protons, such as chloride- and acetate- 
based, allow a higher solubility of cellulose. Following this notion, Ueno et al. [100] studied IL-solvent parameters, including Lewis basicity, solubility and hydrophobicity to infer the most adequate IL for synthetic polymers solubilization, such as poly(methyl methacrylate) (PMMA). The authors verified that to enhance the solubility of polymers like PMMA, the contribution of the non-polar character of both the IL cation and anion must be taken into account. In particular, a correlation has been found between PMMA solubility and the hydrophobicity of the anion of imidazolium-based ILs, rather than with the alkyl chain length of the cationic structure [100].

The high solubility of some polymers in ILs results from favorable interactions occurring between both compounds, including hydrogen-bonding, $\mathrm{n}-\pi, \pi-\pi$, electrostatic and dispersive interactions [102]. However, due to the complexity of ILs when compared to common solvents, additional efforts are required to fully understand the solubilization process at the molecular level, thus allowing the ILs' correct selection for polymer processing.

\section{ILs in the Development of (Bio)Polymer-Based Drug Delivery Systems}

The unlimited possibilities of design allow the development of tailored (bio)polymer drug delivery systems, due not only to the ILs' biopolymer solvation ability, but also due to the possibility of obtaining ILs with polymerizable character. For example, ILs have been applied as reaction media for the synthesis of tailor-made guar gum derivatives through direct and homogeneous esterification of acid chlorides, namely hexanoyl, acryloyl, and 2-chloropropyonyl chlorides [103]. Results show that the degree of substitution of guar gum can be varied (0.12-2.70) by adapting the experimental conditions, such as reaction time. The use of these imidazolium-based media is an appealing alternative to overcome the problem of low and uncontrolled substitution reactions for this biopolymer. Ultimately, the esterification with hexanoyl chloride allowed guar chains with tunable emulsifying properties to be obtained. The acryloyl inclusion, on the other hand, offered the possibility of design reactive precursors, that when subjected to radical cross-linking, might enable the development of $\mathrm{pH}$-sensitive carriers for the sustained drug delivery [103].

Since ILs improve the solubility of both low-water soluble APIs and biopolymers, they further allow new administration routes to be considered, as their application in drug delivery systems is extended. So far, drug polymeric delivery systems comprising ILs and API-ILs have been successfully reported for intravenous [32,104], oral [29,56], topical, and, more extensively, transdermal delivery [71,74,105-107]. In this context, ILs have been investigated in the development of fibers, ionogels, patches and membranes, microemulsions, nanoparticles, and polymerizable systems.

The dissolution of biopolymers in IL media is a simple and effective method to develop delivery systems since some processes, like coating, can be performed in a one-pot/one-step process. Such an example has been verified for cellulose coating onto chitosan hydrogel beads, when dissolving cellulose in $\left[\mathrm{C}_{2} \mathrm{C}_{1} \mathrm{im}\right]\left[\mathrm{CH}_{3} \mathrm{CO}_{2}\right]$ [108]. The cellulose-coated chitosan beads were impregnated with verapamil hydrochloride, a hypertension drug used as model. The resultant beads exhibited sustained release patterns for the drug both in gastric and intestinal environment, achieving a maximum of release from 60 to $300 \mathrm{~min}$, respectively.

The use of ILs has also provided new grafting polymerization [109] and chemical modification [110] media for the design of polymer-based drug delivery systems. Additionally, ILs have enabled the preparation of biopolymer-based systems by eletrospinning [111], solvent casting [112] and by simple incorporation of an API-IL directly into a biopolymer matrix, such as bacterial cellulose [106]. Promising cellulose-based delivery systems have been reported, in the context of topical delivery, for the incorporation of cholinium-based ILs comprising vitamins [113], antioxidants [106], and anti-inflammatory drugs [107]. Such systems allow a fast or controlled release of the API due to the increase in the drug solubility enabled by the API-IL formulation [107,113].

ILs can be applied in delivery systems as components that allow the release profile of stimuli-responsive systems to be tuned. In this field, cholinium-based ILs have been studied to obtain a more controlled release of ionic drugs, such as sodium phosphate 
dexamethasone (DXA), from chitosan-based materials [112]. The obtained films can be applied as $\mathrm{pH}$-responsive drug delivery systems for delivery of DXA and loaded with ionic liquid (cholinium dihydrogen phosphate). The amount of DXA released from films loaded with IL was revealed to be lower than for films without IL, independent of the $\mathrm{pH}$ of the release medium, showing an ability to control the release of the API. The chitosan-based films allow lower total released amounts of DXA at $\mathrm{pH} 4$ compared to the release for $\mathrm{pH} 7$ and at $\mathrm{pH}$ 10. Due to the properties displayed by ILs, such as conductivity, the incorporation of these compounds in the chitosan-based films may additionally allow the development of biocompatible and biodegradable iontophoretic devices.

In a different approach, ILs can be used as alternative gelling agents in drug formulations, with interesting pharmaceutical profiles, and are able to exert direct effects on cell membranes [114]. By using ILs with surface-active behavior and an API, responsive ionogels with improved sustained release profiles of drugs could be obtained. Cetylpyridinium salicylate, for example, forms a temperature-responsive ionogel at a critical gelation concentration, capable of encapsulating in its matrix imatinib mesylate, a chemotherapeutic drug. This ionogel allows different release profiles to be obtained for the API according to the $\mathrm{pH}$ and temperature of the media, the release being faster at body temperature and at $\mathrm{pH}=5$ in accordance with tumoral environment [114].

The development of "smart" systems that can respond to the surrounding environment can also be achieved by the incorporation of responsive motifs of polymers and biopolymers in the intended formulations [115]. These systems can be designed to respond to specific changes in $\mathrm{pH}$, redox and temperature conditions or under the presence of specific enzymes. ILs can be applied differently in the development of these systems, namely: (i) by the modification of (bio)polymers in IL media, where sensitive polymer units are incorporated; (ii) by the design of ILs to add specific properties to the system; and (iii) by the design of polymerizable forms of ILs enabling the synthesis of the so-called polymeric ionic liquids (PILs). PILs are designed by the proper selection of polymerizable moieties, resulting in polyelectrolytes with repeating charged units [116]. Several multi-responsive nanopolymeric systems, based on $\mathrm{pH}$ and temperature stimulus, have been prepared by the copolymerization PILs, specially comprising vinyl moieties with sensitive monomers, resulting in more effective delivery systems with controlled release profiles [33,117]. The copolymerization of these PILs with monomers, such as $\mathrm{N}$-isopropyl acrylamide, might allow delivery systems to be obtained with high entrapment abilities and responsive to body temperature $\left(37-38^{\circ} \mathrm{C}\right)$ and to the $\mathrm{pH}$ environment $(\mathrm{pH}<7)$, conditions particularly relevant for the target delivery of chemotherapeutic drugs [117].

\section{Conclusions and Future Perspectives}

ILs have been shown to be competitive alternatives to the use of organic solvents, co-solvents and surface-active agents to improve API solubility for drug delivery. The solubility enhancements achieved by the use of ILs are several orders of magnitude higher than those obtained in an aqueous medium, being applicable to distinct types of APIs. Despite these promising results, more comprehensive studies regarding the stability of drugs in the novel IL media, while addressing their long-term storage, and the in vivo bioavailability assays of these formulations are still required. Furthermore, other IL classes should be investigated, particularly considering ILs with more biocompatible features in addition to the widely investigated imidazolium-based.

The variety of IL cation-anion combinations also allowed new liquid drugs to be obtained with improved chemical and biological properties, e.g., by avoiding polymorphism concerns and by improving solubility by overcoming the energetic barrier of the enthalpy of melting, and thus improving bioavailability. API-ILs can be designed to provide single or double therapeutic action and to allow different administration routes. The use of ILs as permeation enhancers and as components of microemulsions (acting as oil, water and/or surfactant phases) has improved the topical and transdermal delivery of several APIs, allowing for better permeation across biological membranes. However, the interactions of 
API-ILs and ILs with biological membranes, which is critical to better design effective therapeutics, are scarcely addressed. In addition, the lack of studies on the therapeutic activity improvement and unknown pharmacokinetic and pharmacodynamic parameters of ILs and API-ILs after administration still hinders their envisioned commercial application.

For application in drug delivery, and although promising results have been obtained to date, the use of API-ILs and ILs in combination with different (bio)polymers, as well as research in different types of drug delivery systems, needs to be further investigated. ILs have been shown to be effective alternatives for the solubilization and processing of different types of (bio)polymers commonly applied in drug delivery systems. Their solubilization in IL media allows for their direct use in drug delivery systems preparation, minimizing the number of required steps. Therefore, understanding the IL-(bio)polymer interactions and mechanisms of solubilization is key for their design to obtain more effective drug delivery profiles. Furthermore, stimuli-responsive systems involving ILs and polymers able to deliver drugs in target tissues must be investigated.

Although promising IL-based drug delivery systems have been reported, the lack of comprehensive studies on this topic that could assist the conscious development of novel drug delivery options still limits their finest design. In addition, in all described options, they require regulatory agency approval, representing a long path to their acceptance and commercialization. Nevertheless, the results and advances reported hitherto on the multiple roles of ILs in the drug delivery field encourage new ways of taking advantage of their unique properties heading towards their implementation in the market.

Author Contributions: S.N.P., writing and original draft preparation; M.G.F., conceptualization; C.S.R.F., A.J.D.S. and M.G.F., review-editing and supervision. All authors have read and agreed to the published version of the manuscript.

Funding: This work was developed within the scope of the project CICECO-Aveiro Institute of Materials, UIDB/50011/2020 \& UIDP/50011/2020, financed by national funds through the FCT/MEC and when appropriate co-financed by FEDER under the PT2020 Partnership Agreement. This work was financially supported by the project IonCytDevice (POCI-01-0145-FEDER-031106, PTCD/BTABTA/31106/2017) funded by FEDER, through COMPETE2020-Programa Operacional Competitividade e Internacionalização (POCI), and by national funds (OE), through FCT/MCTE). S. N. Pedro acknowledges the PhD grant SFRH/BD/132584/2017.

Conflicts of Interest: The authors declare no conflict of interest.

Entry Link on the Encyclopedia Platform: https:/ / encyclopedia.pub/3941

\section{ILs Abbreviations}

\begin{tabular}{|c|c|}
\hline$\left[\mathrm{C}_{2} \mathrm{C}_{1} \mathrm{im}\right]\left[\mathrm{CH}_{3} \mathrm{CO}_{2}\right]$ & 1-ethyl-3-methylimidazolium acetate \\
\hline$\left[\mathrm{C}_{4} \mathrm{NH}_{3}\right]\left[\mathrm{CH}_{3} \mathrm{CO}_{2}\right]$ & $\mathrm{N}$-butylammonium acetate \\
\hline$\left[\mathrm{C}_{6} \mathrm{NH}_{3}\right]\left[\mathrm{CH}_{3} \mathrm{CO}_{2}\right]$ & N-hexylammonium acetate \\
\hline$\left[\mathrm{C}_{8} \mathrm{NH}_{3}\right]\left[\mathrm{CH}_{3} \mathrm{CO}_{2}\right]$ & N-octylammonium acetate \\
\hline$\left[\mathrm{C}_{4} \mathrm{NH}_{3}\right][$ oleate $]$ & N-butylammonium oleate \\
\hline$\left[\mathrm{C}_{6} \mathrm{NH}_{3}\right][$ oleate $]$ & N-hexylammonium oleate \\
\hline$\left[\mathrm{C}_{8} \mathrm{NH}_{3}\right][$ oleate $]$ & N-octylammonium oleate \\
\hline$\left[\mathrm{C}_{4} \mathrm{C}_{1} \mathrm{im}\right]\left[\mathrm{BF}_{4}\right]$ & 1-butyl-3-methylimidazolium tetrafluoroborate \\
\hline$\left[\mathrm{C}_{6} \mathrm{C}_{1} \mathrm{im}\right]\left[\mathrm{BF}_{4}\right]$ & 1-hexyl-3-methylimidazolium tetrafluoroborate \\
\hline$\left[\mathrm{C}_{8} \mathrm{C}_{1} \mathrm{im}\right]\left[\mathrm{BF}_{4}\right]$ & 1-octyl-3-methylimidazolium tetrafluoroborate \\
\hline$\left[\mathrm{C}_{4} \mathrm{C}_{1} \mathrm{im}\right]\left[\mathrm{PF}_{6}\right]$ & 1-butyl-3-methylimidazolium hexafluorophosphate \\
\hline$\left[\mathrm{C}_{8} \mathrm{C}_{1} \mathrm{im}\right]\left[\mathrm{PF}_{6}\right]$ & 1-octyl-3-methylimidazolium hexafluorophosphate \\
\hline$\left[\mathrm{C}_{6} \mathrm{C}_{6} \mathrm{OCOpy}\right]\left[\mathrm{N}(\mathrm{CN})_{2}\right]$ & 1-hexyl-3-hexyloxycarbonylpyridinium dicyanamide \\
\hline$\left[\mathrm{C}_{6} \mathrm{C}_{6} \mathrm{OCOpy}\right]\left[\mathrm{NTf}_{2}\right]$ & $\begin{array}{l}\text { 1-hexyl-3-hexyloxycarbonylpyridinium } \\
\text { bis(trifluoromethylsulfonyl)imide }\end{array}$ \\
\hline$\left[\mathrm{C}_{6} \mathrm{C}_{1} \mathrm{im}\right]\left[\mathrm{PF}_{6}\right]$ & 1-hexyl-3-methylimidazolium hexafluorophosphate \\
\hline$\left[\mathrm{C}_{4} \mathrm{C}_{1} \mathrm{im}\right] \mathrm{Br}$ & 1-butyl-3-methylimidazolium bromide \\
\hline [Ch][Gly] & Cholinium glycinate \\
\hline [Ch][Ala] & Cholinium alaninate \\
\hline
\end{tabular}






Cholinium prolinate
Cholinium phenylalanine
Cholinium isoleucine
Cholinium serinate
Cholinium leucinate
Ranitidinium docusate
1-butyl-3-methylimidazolium chloride
1-butyl-3-methylimidazolium acetate
1-ethyl-3-methylimidazolium chloride
1-allyl-3-methylimidazolium bromide
1-allyl-3-methylimidazolium chloride
1-methy-3-(3-sulfopropyl) imidazolium acetate
1-butyl-3-(3- sulfopropyl) imidazolium acetate
1-butyl-3-pyridinium tetrafluoroborate
1-ethyl-3-methylimidazolium bis(trifluoromethanesulfonyl)imide
1-butyl-3-methylimidazolium bis(trifluoromethylsulfonyl)imide
1-ethyl-3-methylimidazolium trifluoromethanesulfonate
1-butyl-3-methylimidazolium trifluoromethanesulfonate
1-ethyl-3-methylimidazolium tetrafluoroborate
1-octyl-3-methylimidazolium bis[trifluoromethylsulfonyl]amide
1-butyl-3-methylimidazolium formate

\section{References}

1. Tiwari, G.; Tiwari, R.; Bannerjee, S.; Bhati, L.; Pandey, S.; Pandey, P.; Sriwastawa, B. Drug delivery systems: An updated review. Int. J. Pharm. Investig. 2012, 2, 2. [CrossRef] [PubMed]

2. Shamshina, J.L.; Rogers, R.D. Overcoming the problems of solid-state drug formulations with ionic liquids. Ther. Deliv. 2014, 5, 489-491. [CrossRef] [PubMed]

3. Byrn, S.; Pfeiffer, R.; Ganey, M.; Hoiber, C.; Poochikian, G. Pharmaceutical Solids: A Strategic Approach to Regulatory Considerations. Pharm. Res. 1995, 12, 945-954. [CrossRef] [PubMed]

4. Jain, K.K. Current Status and Future Prospects of Drug Delivery Systems. Methods Mol. Biol. 2014, 1141, 1-56. [PubMed]

5. Li, C.; Wang, J.; Wang, Y.; Gao, H.; Wei, G.; Huang, Y.; Yu, H.; Gan, Y. Recent progress in drug delivery. Acta Pharm. Sin. B 2019, 9 1145-1162. [CrossRef] [PubMed]

6. Barenholz, Y.C. Doxil ${ }^{\circledR}$ —The first FDA-approved nano-drug: Lessons learned. J. Control Release 2012, 160, 117-134. [CrossRef]

7. Stone, N.R.H.; Bicanic, T.; Salim, R.; Hope, W. Liposomal Amphotericin B (AmBisome ${ }^{\circledR}$ ): A review of the pharmacokinetics, pharmacodynamics, clinical experience and future directions. Eur. PMC Funders Group 2017, 76, 485-500. [CrossRef]

8. Cue, B.W.; Zhang, J. Green process chemistry in the pharmaceutical industry. Green Chem. Lett. Rev. 2009, 2, 193-211. [CrossRef]

9. Riebesehl, B.U. Drug Delivery with Organic Solvents or Colloidal Dispersed Systems. In The Practice of Medicinal Chemistry, 4th ed.; Elsevier Ltd.: Amsterdam, The Netherlands, 2015; pp. 699-722.

10. Jain, N.; Kumar, A.; Chauhan, S.; Chauhan, S.M.S. Chemical and biochemical transformations in ionic liquids. Tetrahedron 2005, 61, 1015-1060. [CrossRef]

11. Olivier-bourbigou, H.; Magna, L. Ionic liquids: Perspectives for organic and catalytic reactions. J. Mol. Catal. A Chem. 2002, 183, 419-437. [CrossRef]

12. Cave, G.W.V.; Raston, L.; Scott, J.L. Recent advances in solventless organic reactions: Towards benign synthesis with remarkable versatility. Chem. Commun. 2001, 2159-2169. [CrossRef]

13. Freire, M.G.; Cláudio, A.F.M.; Araújo, J.M.M.; Coutinho, J.A.P.; Marrucho, I.M.; Canongia Lopes, J.N.; Rebelo, L.P.N. Aqueous biphasic systems: A boost brought about by using ionic liquids. Chem. Soc. Rev. 2012, 41, 4966-4995. [CrossRef] [PubMed]

14. Earle, M.J.; Esperança, J.M.S.S.; Gile, M.; Lopes, J.N.C.; Rebelo, L.P.N.; Magee, J.W.; Seddon, K.R.; Widegren, J.A. The distillation and volatility of ionic liquids. Nature 2005, 439, 831-834. [CrossRef] [PubMed]

15. Cláudio, A.F.M.; Neves, M.C.; Shimizu, K.; Canongia Lopes, J.N.; Freire, M.G.; Coutinho, J.A.P. The magic of aqueous solutions of ionic liquids: Ionic liquids as a powerful class of catanionic hydrotropes. Green Chem. 2015, 17, 3948-3963. [CrossRef] [PubMed]

16. Hough, W.L.; Rogers, R.D. Ionic Liquids Then and Now: From Solvents to Materials to Active Pharmaceutical Ingredients. Bull. Chem. Soc. Jpn. 2007, 80, 2262-2269. [CrossRef]

17. Chowdhury, M.R.; Moshikur, R.M.; Wakabayashi, R.; Tahara, Y.; Kamiya, N.; Moniruzzaman, M.; Goto, M. Ionic-Liquid-Based Paclitaxel Preparation: A New Potential Formulation for Cancer Treatment. Mol. Pharm. 2018, 15, 2484-2488. [CrossRef]

18. Czerniak, K.; Walkiewicz, F. Synthesis and antioxidant properties of dicationic ionic liquids. New J. Chem. 2017, 41, 530-539. [CrossRef]

19. Ferreira, A.M.; Morais, E.M.; Leite, A.C.; Mohamadou, A.; Holmbom, B.; Holmbom, T.; Neves, B.M.; Coutinho, J.A.P.; Freire, M.G.; Silvestre, A.J. Enhanced Extraction and Biological Activity of 7- hydroxymatairesinol obtained from Norway Spruce knots using Aqueous Solutions of Ionic Liquids. Green Chem. 2017, 19, 2626-2635. [CrossRef] 
20. Kumar, V.; Malhotra, S.V. Study on the potential anti-cancer activity of phosphonium and ammonium-based ionic liquids. Bioorg. Med. Chem. Lett. 2009, 19, 4643-4646. [CrossRef]

21. Malhotra, S.V.; Kumar, V. A profile of the in vitro anti-tumor activity of imidazolium-based ionic liquids. Bioorg. Med. Chem. Lett. 2010, 20, 581-585. [CrossRef]

22. Zheng, W.; Huang, W.; Song, Z.; Tang, Z.; Sun, W. Insight into Structure-Antibacterial Activity of Amino Cation- based and Acetate Anion-based Ionic Liquids from the Computational Interaction with POPC Phospholipid Bilayer. Phys. Chem. Chem. Phys. 2020, 19, 15573-15581. [CrossRef] [PubMed]

23. Carson, L.; Chau, P.K.W.; Earle, M.J.; Gilea, M.A.; Gilmore, B.F.; Gorman, S.P.; Mccann, T.; Seddon, K.R. Antibiofilm activities of 1-alkyl-3-methylimidazolium chloride ionic liquids. Green Chem. 2009, 44, 492-497. [CrossRef]

24. Anvari, S.; Hajfarajollah, H.; Mokhtarani, B.; Enayati, M. Antibacterial and anti-adhesive properties of ionic liquids with various cationic and anionic heads toward pathogenic bacteria. J. Mol. Liq. 2016, 221, 685-690. [CrossRef]

25. Taylor, P.; Nancharaiah, Y.V.; Reddy, G.K.K.; Lalithamanasa, P.; Venugopalan, V.P. The ionic liquid 1-alkyl-3-methylimidazolium demonstrates comparable antimicrobial and antibiofilm behavior to a cationic surfactant. Biofouling J. Bioadhesion Biofilm 2012, 28, 1141-1149. [CrossRef]

26. Docherty, K.M.; Kulpa, C.F. Toxicity and antimicrobial activity of imidazolium and pyridinium ionic liquids. Green Chem. 2005, 7, 185-189. [CrossRef]

27. Shamshina, J.L.; Barber, P.S.; Rogers, R.D. Ionic liquids in drug delivery. Expert Opin. Drug Deliv. 2013, 10, 1367-1381. [CrossRef]

28. Cojocaru, O.A.; Bica, K.; Gurau, G.; Narita, A.; Mccrary, P.D.; Shamshina, J.L.; Barber, S.; Rogers, R.D. Prodrug ionic liquids: Functionalizing neutral active ionic liquid form. Med. Chem. Commun. 2013, 4, 559-563. [CrossRef]

29. Zhang, L.; Liu, J.; Tian, T.; Gao, Y.; Ji, X.; Li, Z. Pharmaceutically Active Ionic Liquid Self-Assembled Vesicles for the Application as an Efficient Drug Delivery System. ChemPhysChem 2013, 14, 3454-3457. [CrossRef]

30. Trivedi, T.J.; Srivastava, D.N.; Rogers, R.D.; Kumar, A. Agarose processing in protic and mixed protic-aprotic ionic liquids: Dissolution, regeneration and high conductivity, high strength ionogels. Green Chem. 2012, 14, 2831-2839. [CrossRef]

31. Viau, L.; Tourné-Péteilh, C.; Devoisselle, J.M.; Vioux, A. Ionogels as drug delivery system: One-step sol-gel synthesis using imidazolium ibuprofenate ionic liquid. Chem. Commun. 2010, 46, 228-230. [CrossRef]

32. Tang, W.; Liu, B.; Wang, S.; Liu, T.; Fu, C.; Ren, X.; Tan, L.; Duan, W.; Meng, X. Doxorubicin-loaded Ionic Liquid-Polydopamine nanoparticles for combined chemotherapy and microwave thermal therapy of cancer. RSC Adv. 2016, 6, 32434-32440. [CrossRef]

33. Seo, J.W.; Hwang, J.Y.; Shin, U.S. Ionic liquid-doped and p-NIPAAm-based copolymer (p-NIBIm): Extraordinary drug-entrapping and -releasing behaviors at $38-42^{\circ} \mathrm{C}$. RSC Adv. 2014, 4, 26738-26747. [CrossRef]

34. Adawiyah, N.; Moniruzzaman, M.; Hawatulaila, S.; Goto, M. Ionic liquids as a potential tool for drug delivery systems. Med. Chem. Commun. 2016, 7, 1881-1897. [CrossRef]

35. Mizuuchi, H.; Jaitely, V.; Murdan, S.; Florence, A.T. Room temperature ionic liquids and their mixtures: Potential pharmaceutical solvents. Eur. J. Pharm. Sci. 2008, 33, 326-331. [CrossRef]

36. Jaitely, V.; Mizuuchi, H.; Florence, A.T. Current-stimulated release of solutes solubilized in water-immiscible room temperature ionic liquids (RTILs). J. Drug Target. 2010, 18, 787-793. [CrossRef]

37. Williams, H.D.; Sahbaz, Y.; Ford, L.; Nguyen, T.H.; Scammells, P.J.; Porter, C.J.H. Ionic liquids provide unique opportunities for oral drug delivery: Structure optimization and in vivo evidence of utility. Chem. Commun. 2014, 50, 1688-1690. [CrossRef] [PubMed]

38. McCrary, P.D.; Beasley, P.A.; Gurau, G.; Narita, A.; Barber, P.S.; Cojocaru, O.A.; Rogers, R.D. Drug specific, tuning of an ionic liquid's hydrophilic-lipophilic balance to improve water solubility of poorly soluble active pharmaceutical ingredients. New $J$. Chem. 2013, 37, 2196-2202. [CrossRef]

39. Goindi, S.; Kaur, R.; Kaur, R. An ionic liquid-in-water microemulsion as a potential carrier for topical delivery of poorly water soluble drug: Development, ex-vivo and in-vivo evaluation. Int. J. Pharm. 2015, 495, 913-923. [CrossRef] [PubMed]

40. Smith, K.B.; Bridson, R.H.; Leeke, G.A. Solubilities of pharmaceutical compounds in ionic liquids. J. Chem. Eng. Data 2011, 56, 2039-2043. [CrossRef]

41. Goindi, S.; Arora, P.; Kumar, N.; Puri, A. Development of novel ionic liquid-based microemulsion formulation for dermal delivery of 5-fluorouracil. AAPS PharmSciTech 2014, 15, 810-821. [CrossRef] [PubMed]

42. Kalepu, S.; Nekkanti, V. Insoluble drug delivery strategies: Review of recent advances and business prospects. Acta Pharm. Sin. B 2015, 5, 442-453. [CrossRef]

43. Savjani, K.T.; Gajjar, A.K.; Savjani, J.K. Drug Solubility: Importance and Enhancement Techniques. ISRN Pharm. 2012, $2012,195727$. [CrossRef] [PubMed]

44. Brittain, H.G.; Grant, D.J.R. Effects of Polymorphism and Solid-State Solvation on Solubility and Dissolution Rate. In Polymorphism in Pharmaceutical Solids, 2nd ed.; CRC Press: Boca Raton, FL, USA, 2009; pp. 436-480.

45. Censi, R.; Martino, P. Di Polymorph Impact on the Bioavailability and Stability of Poorly Soluble Drugs. Molecules 2015, 20, 18759-18776. [CrossRef] [PubMed]

46. Rubio-Bonilla, M.V.; Londono, R.; Rubio, A. Liquid Dosage Forms. In Pharmaceutical Manufacturing Handbook: Production and Processes; John Wiley Sons, Inc.: Hoboken, NJ, USA, 2008; pp. 313-344.

47. Hough, W.L.; Smiglak, M.; Rodríguez, H.; Swatloski, R.P.; Spear, S.K.; Daly, D.T.; Pernak, J.; Grisel, J.E.; Carliss, R.D.; Soutullo, M.D.; et al. The third evolution of ionic liquids: Active pharmaceutical ingredients. New J. Chem. 2007, 31, 1429. [CrossRef] 
48. Zhao, H.; Holmes, S.S.; Baker, G.A.; Challa, S.; Bose, H.S.; Song, Z. Ionic derivatives of betulinic acid as novel HIV-1 protease inhibitors. J. Enzyme Inhib. Med. Chem. 2012, 27, 715-721. [CrossRef]

49. Bica, K.; Rogers, R.D. Confused ionic liquid ions-A "liquification" and dosage strategy for pharmaceutically active salts. Chem. Commun. 2010, 46, 1215-1217. [CrossRef]

50. Bica, K.; Rijksen, C.; Nieuwenhuyzena, M.; Rogers, R.D. In search of pure liquid salt forms of aspirin: Ionic liquid approaches with acetylsalicylic acid and salicylic acid. Phys. Chem. Chem. Phys. 2010, 12, 2011-2017. [CrossRef]

51. Frizzo, C.P.; Wust, K.; Tier, A.Z.; Vaucher, R.A.; Bolzan, L.P.; Terra, S.; Martins, M.A.P. Novel ibuprofenate- and docusate-based ionic liquids: Emergence of antimicrobial activity. RSC Adv. 2016, 6, 100476-100486. [CrossRef]

52. Rogers, R.D.; Daly, D.T.; Swatloski, R.P.; Hough-Troutman, W.L.; Hough-Troutman, J.J.H.L.; Marcin, S.; Juliusz, P.; Spear, S.K. Multifunctional Ionic Liquid Compositions for Overcoming Polymorphism and Imparting Improved Properties for Active Pharmaceutical, Biological, Nutritional and Energetic Ingredients. U.S. Patent No. 8,232,265, 18 October 2012.

53. Fernandez-Stefanuto, V.; Tojo, E. New Active Pharmaceutical Ingredient-Ionic Liquids (API-ILs) Derived from Indomethacin and Mebendazole. Proceedings 2019, 9, 48. [CrossRef]

54. Sastry, N.V.; Singh, D.K. Surfactant and Gelation Properties of Acetylsalicylate Based Room Temperature Ionic Liquid in Aqueous Media. Langmuir 2016, 32, 10000-10016. [CrossRef]

55. Miwa, Y.; Hamamoto, H.; Ishida, T. Lidocaine self-sacrificially improves the skin permeation of the acidic and poorly water-soluble drug etodolac via its transformation into an ionic liquid. Eur. J. Pharm. Biopharm. 2016, 102, 92-100. [CrossRef]

56. Bica, K.; Rodríguez, H.; Gurau, G.; Cojocaru, O.A.; Riisager, A.; Fehrmann, R.; Rogers, R.D. Pharmaceutically active ionic liquids with solids handling, enhanced thermal stability, and fast release. Chem. Commun. 2012, 48, 5422-5424. [CrossRef]

57. Stoimenovski, J.; Dean, P.M.; Izgorodina, E.I.; Macfarlane, D.R. Protic pharmaceutical ionic liquids and solids: Aspects of protonics. Faraday Discuss. 2012, 154, 335-352. [CrossRef]

58. Pinto, P.C.A.G.; Ribeiro, D.M.G.P.; Azevedo, A.M.O.; Justina, V.D.; Cunha, E.; Bica, K.; Vasiloiu, M.; Reis, S.; Saraiva, M.L.M.F.S. Active pharmaceutical ingredients based on salicylate ionic liquids: Insights into the evaluation of pharmaceutical profiles. New $J$. Chem. 2013, 37, 4095-4102. [CrossRef]

59. Alves, F.; Oliveira, F.S.; Oder, B.S.; Matos, C.; Marrucho, I.M. Synthesis, Characterization, and Liposome Partition of a Novel Tetracycline Derivative Using the Ionic Liquids Framework. J. Pharma Scienc. 2013, 102, 1504-1512. [CrossRef] [PubMed]

60. Miwa, Y.; Hamamoto, H.; Hikake, S.; Kuwabara, Y. A Phase I, Randomized, Open-Label, Cross-Over Study of the Pharmacokinetics, Dermal Tolerability, and Safety of MRX-7EAT Etodolac-Lidocaine Topical Patch in Healthy Volunteers. J. Pain 2013, 14, S72. [CrossRef]

61. Megwa, S.A.; Cross, S.E.; Benson, H.A.E.; Roberts, M.S. Ion-pair Formation as a Strategy to Enhance Topical Delivery of Salicylic Acid. J. Pharm. Pharmacol. 2000, 919-928. [CrossRef] [PubMed]

62. Stoimenovski, J.; Macfarlane, D.R. Enhanced membrane transport of pharmaceutically active protic ionic liquids. Chem. Commun. 2011, 11429-11431. [CrossRef]

63. Zavgorodnya, O.; Shamshina, J.L.; Mittenthal, M.; McCrary, P.D.; Rachiero, G.P.; Titi, H.M.; Rogers, R.D. Polyethylene Glycol Derivatization of the Non-active Ion in Active Pharmaceutical Ingredient Ionic Liquids Enhances Transdermal Delivery. New J. Chem. 2017, 41, 1499-1508. [CrossRef]

64. Furukawa, S.; Hattori, G.; Sakai, S.; Kamiya, N. Highly Efficient and Low Toxic Skin Penetrants Composed of Amino Acid Ionic Liquids. RSC Adv. 2016, 6, 87753-87755. [CrossRef]

65. Mahajan, S.; Sharma, R.; Mahajan, R.K. An Investigation of Drug Binding Ability of a Surface Active Ionic Liquid: Micellization, Electrochemical, and Spectroscopic Studies. Langmuir 2012, 18, 17238-17246. [CrossRef] [PubMed]

66. Jing, B.; Lan, N.; Qiu, J.; Zhu, Y. Interaction of Ionic Liquids with Lipid Bilayer: A Biophysical Study of Ionic Liquid Cytotoxicity. J. Phys. Chem. B 2016, 120, 2781-2789. [CrossRef] [PubMed]

67. Benedetto, A.; Bingham, R.J.; Ballone, P. Structure and dynamics of POPC bilayers in water solutions of room temperature ionic liquids. J. Chem. Phys. 2015, 142, 1-21. [CrossRef] [PubMed]

68. Benedetto, A.; Heinrich, F.; Gonzalez, M.A.; Fragneto, G.; Watkins, E.; Ballone, P. Structure and Stability of Phospholipid Bilayers Hydrated by a Room-Temperature Ionic Liquid/Water Solution: A Neutron Reflectometry Study. J. Phys. Chem. B. 2014, 118, 12192-12206. [CrossRef]

69. Zakrewsky, M.; Lovejoy, K.S.; Kern, T.L.; Miller, T.E.; Le, V.; Nagy, A. Ionic liquids as a class of materials for transdermal delivery and pathogen neutralization. Proc. Natl. Acad. Sci. USA 2014, 111, 13313-13318. [CrossRef]

70. Kubota, K.; Shibata, A.; Yamaguchi, T. The molecular assembly of the ionic liquid/aliphatic carboxylic acid/aliphatic amine as effective and safety transdermal permeation enhancers. Eur. J. Pharm. Sci. 2016, 86, 75-83. [CrossRef]

71. Zech, O.; Thomaier, S.; Kolodziejski, A.; Touraud, D.; Grillo, I.; Kunz, W. Ionic Liquids in Microemulsions-A Concept To Extend the Conventional Thermal Stability Range of Microemulsions. Chem. Eur. J. 2010, 16, 783-786. [CrossRef]

72. Bharmoria, P.; Singh, T.; Kumar, A. Complexation of chitosan with surfactant like ionic liquids: Molecular interactions and preparation of chitosan nanoparticles. J. Colloid Interface Sci. 2013, 407, 361-369. [CrossRef]

73. Solans, C.; García-Celma, M.J. Garcia-Celma Microemulsions and Nano-emulsions for Cosmetic Applications. In Cosmetic Science and Technology; Elsevier Ltd.: Amsterdam, The Netherlands, 2017; pp. 507-518.

74. Dobler, D.; Schmidts, T.; Klingenhöfer, I.; Runkel, F. Ionic liquids as ingredients in topical drug delivery systems. Int. J. Pharm. 2013, 441, 620-627. [CrossRef] 
75. Islam, R.; Chowdhury, R.; Wakabayashi, R.; Kamiya, N. Ionic Liquid-In-Oil Microemulsions Prepared with Biocompatible Choline Carboxylic Acids for Improving the Transdermal Delivery of a Sparingly Soluble Drug. Pharmaceutics 2020, 12, 392. [CrossRef]

76. Silva, S.S.; Oliveira, N.M.; Oliveira, M.B.; Soares, D.P.; Naskar, D.; Mano, J.F.; Kundu, S.C.; Reis, R.L. Fabrication and characterization of Eri silk fibers-based sponges for biomedical application. Acta Biomater. 2016, 32, 178-189. [CrossRef] [PubMed]

77. Phillips, D.M.; Drummy, L.F.; Conrady, D.G.; Fox, D.M.; Naik, R.R.; Stone, M.O.; Trulove, P.C.; De Long, H.C.; Mantz, R.A. Dissolution and Regeneration of Bombyx mori Silk Fibroin Using Ionic Liquids. JACS 2004, 126, 14350-14351. [CrossRef] [PubMed]

78. Tan, X.; Li, X.; Chen, L.; Xie, F. Solubility of starch and microcrystalline cellulose in 1-ethyl-3-methylimidazolium acetate ionic liquid and solution rheological properties. Phys. Chem. Chem. Phys. 2016, 18, 27584-27593. [CrossRef] [PubMed]

79. Xu, B.; Li, Q.; Zhuang, L.; Wang, Q.; Li, C.; Wang, G.; Xie, F.; Halley, P.J. Dissolution and Regeneration Behavior of Chitosan in 3-methyl-1-(ethylacetyl)imidazolium Chloride. Fibers Polym. 2016, 17, 1741-1748. [CrossRef]

80. Sun, Y.; Qing, M.; Chen, L.; Liu, J.; Zhong, F.; Jiang, P.; Wang, G.; Zhuang, L. Chitosan dissolution with sulfopropyl imidazolium Brönsted acidic ionic liquids. J. Mol. Liq. 2019, 293, 111533. [CrossRef]

81. Takada, A.; Kadokawa, J. Fabrication and Characterization of Polysaccharide Ion Gels with Ionic Liquids and Their Further Conversion into Value-Added Sustainable Materials. Biomolecules 2015, 5, 244-262. [CrossRef]

82. Sharma, M.; Mondal, D.; Mukesh, C.; Prasad, K. Solvent responsive healing of guar gum and guar gum-multiwalled carbon nanotube nanocomposite gels prepared in an ionic liquid. RSC Adv. 2013, 3, 16509-16515. [CrossRef]

83. Remsing, R.C.; Swatloski, R.P.; Rogers, D.; Moyna, G. Mechanism of cellulose dissolution in the ionic liquid 1-n-butyl-3methylimidazolium chloride: $\mathrm{A}^{13} \mathrm{C}$ and ${ }^{35 / 37} \mathrm{Cl}$ NMR relaxation study on model systems. Chem. Commun. 2006, 1271-1273. [CrossRef]

84. Wang, W.; Zhu, J.; Wang, X.; Huang, Y.; Wang, Z. Dissolution Behavior of Chitin in Ionic Liquids Dissolution Behavior of Chitin in Ionic Liquids. J. Macromol. Sci. Part B Phys. 2010, 49, 528-541. [CrossRef]

85. Qin, Y.; Lu, X.; Sun, N.; Rogers, R.D. Dissolution or extraction of crustacean shells using ionic liquids to obtain high molecular weight purified chitin and direct production of chitin films and fibers. Green Chem. 2010, 12, 968-997. [CrossRef]

86. Shamshina, J.L.; Barber, P.S.; Gurau, G.; Griggs, C.S.; Rogers, R.D. Pulping of crustacean waste using ionic liquids: To extract or not to extract. ACS Sustain. Chem. Eng. 2016, 4, 6072-6081. [CrossRef]

87. Shamshina, J.L.; Rogers, R.D. Are Ionic Liquids Enabling Technology? Startup to Scale-Up to Find Out. In Commercial Applications of Ionic Liquids, 1st ed.; Springer: Berlin/Heidelberg, Germany, 2020.

88. Chen, Q.; Xu, A.; Li, Z.; Zhang, S. Influence of anionic structure on the dissolution of chitosan in 1-butyl-3-methylimidazoliumbased ionic liquids. Green Chem. 2011, 13, 3446-3452. [CrossRef]

89. Guerrero-Sanchez, C.; Erdmenger, T.; Petr, S.; Schubert, U.S. Water-Soluble Ionic Liquids as Novel Stabilizers in Suspension Polymerization Reactions: Engineering Polymer Beads. Chemistry 2006, 9036-9045. [CrossRef] [PubMed]

90. Patil, C.M.; Meshram, J.S.; Borse, A.U. Ionic liquid: Green solvent for the synthesis of cellulose/guar gum/PVA biocomposite. Green Mater. 2018, 6, 23-26. [CrossRef]

91. Silva, S.S.; Santos, T.C.; Cerqueira, M.T.; Marques, A.P.; Reys, L.L. The use of ionic liquids in the processing of chitosan / silk hydrogels for biomedical applications. Green Chem. 2012, 14, 1463-1470. [CrossRef]

92. Lv, F.; Wang, C.; Zhu, P. Characterization of chitosan microparticles reinforced cellulose biocomposite sponges regenerated from ionic liquid. Cellulose 2014, 21, 4405-4418. [CrossRef]

93. Pereira, J.F.B.; Kurnia, K.A.; Freire, M.G.; Coutinho, J.A.P.; Rogers, R.D. Controlling the Formation of Ionic-Liquid-based Aqueous Biphasic Systems by Changing the Hydrogen-Bonding Ability of Polyethylene Glycol End Groups. ChemPhysChem 2015, 16, 2219-2225. [CrossRef]

94. Rodríguez, H.; Francisco, M.; Rahman, M.; Sun, N.; Rogers, R.D. Biphasic liquid mixtures of ionic liquids and polyethylene glycols. Phys. Chem. Chem. Phys. 2009, 11, 10916-10922. [CrossRef]

95. Noda, A.; Watanabe, M. Highly conductive polymer electrolytes prepared by in situ polymerization of vinyl monomers in room temperature molten salts. Electrochim. Acta 2000, 45, 1265-1270. [CrossRef]

96. Triolo, A.; Russina, O.; Keiderling, U.; Kohlbrecher, J. Morphology of poly(ethylene oxide) dissolved in a room temperature ionic liquid: A small angle neutron scattering study. J. Phys. Chem. B 2006, 110, 1513-1515. [CrossRef]

97. Kodama, K.; Tsuda, R.; Niitsuma, K.; Tamura, T.; Ueki, T.; Kokubo, H.; Watanabe, M. Structural effects of polyethers and ionic liquids in their binary mixtures on lower critical solution temperature liquid-liquid phase separation. Polym. J. 2011, 43, 242-248. [CrossRef]

98. Benton, M.G.; Brazel, C.S. Effect of Room-Temperature Ionic Liquids as Replacements for Volatile Organic Solvents in Free-Radical Polymerization. ACS Symp. Ser. 2002, 818, 125-133. [CrossRef]

99. Chen, Y.; Zhang, Y.; Ke, F.; Zhou, J.; Wang, H.; Liang, D. Solubility of neutral and charged polymers in ionic liquids studied by laser light scattering. Polymer 2011, 52, 481-488. [CrossRef]

100. Ueno, K.; Fukai, T.; Nagatsuka, T.; Yasuda, T.; Watanabe, M. Solubility of poly(methyl methacrylate) in ionic liquids in relation to solvent parameters. Langmuir 2014, 30, 3228-3235. [CrossRef] [PubMed]

101. Lu, B.; Xu, A.; Wang, J. Cation does matter: How cationic structure affects the dissolution of cellulose in ionic liquids. Green Chem. 2014, 16, 1326-1335. [CrossRef]

102. Winterton, N. Solubilization of polymers by ionic liquids. J. Mater. Chem. 2006, 16, 4281-4293. [CrossRef] 
103. Chem, P.; Lacroix, C.; Sultan, E. Functional galactomannan platform from convenient esterification in imidazolium-based ionic liquids. Polym. Chem. 2012, 3, 538-546. [CrossRef]

104. Liu, Y.; Huang, Y.; Boamah, P.O.; Cao, L.; Zhang, Q.; Lu, Z.; Li, H. Homogeneous synthesis of linoleic acid-grafted chitosan oligosaccharide in ionic liquid and its self-assembly performance in aqueous solution. J. Appl. Polym. Sci. 2015, 132, 1-8. [CrossRef]

105. Sanan, R.; Kaur, R.; Mahajan, R.K. Micellar Transitions in Catanionic Ionic liquid-Ibuprofen Aqueous Mixtures, Effects of Composition and Dilution. RSC Adv. 2014, 4, 64877-64889. [CrossRef]

106. Morais, E.S.; Silva, N.H.C.S.; Sintra, T.E.; Santos, S.A.O.; Neves, B.M.; Almeida, I.F.; Costa, P.C.; Correia-Sá, I.; Ventura, S.P.M.; Silvestre, A.J.D.; et al. Anti-inflammatory and antioxidant nanostructured cellulose membranes loaded with phenolic-based ionic liquids for cutaneous application. Carbohydr. Polym. 2019, 206, 187-197. [CrossRef] [PubMed]

107. Chantereau, G.; Sharma, M.; Abednejad, A.; Neves, B.M.; Se, G.; Freire, M.G.; Freire, C.S.R.; Silvestre, A.J.D. Design of Nonsteroidal Anti-Inflammatory Drug-Based Ionic Liquids with Improved Water Solubility and Drug Delivery. ACS Sustain. Chem. Eng. 2019, 7, 14126-14134. [CrossRef]

108. Song, M.H.; Phuong, T.; Pham, T.; Yun, Y.S. Ionic liquid-assisted cellulose coating of chitosan hydrogel beads and their application as drug carriers. Sci. Rep. 2020, 1-8. [CrossRef] [PubMed]

109. Dong, H.; Xu, Q.; Li, Y.; Mo, S.; Cai, S.; Liu, L. The synthesis of biodegradable graft copolymer cellulose-graft-poly(l-lactide) and the study of its controlled drug release. Colloids Surf. B Biointerfaces 2008, 66, 26-33. [CrossRef] [PubMed]

110. Pyne, A.; Kuchlyan, J.; Maiti, C.; Dhara, D.; Sarkar, N. A Cholesterol Based Surface Active Ionic Liquid That Can Form Microemulsions and Spontaneous Vesicles. Langmuir 2017, 33, 5891-5899. [CrossRef] [PubMed]

111. Hou, L.; Zhang, X.; Mikael, P.E.; Lin, L.; Dong, W.; Zheng, Y.; Simmons, T.J.; Zhang, F.; Linhardt, R.J. Biodegradable and Bioactive PCL-PGS Core-Shell Fibers for Tissue Engineering. ACS Omega 2017, 2, 6321-6328. [CrossRef] [PubMed]

112. Dias, A.M.A.; Cortez, A.R.; Barsan, M.M.; Santos, J.B.; Brett, C.M.A.; De Sousa, H.C. Development of greener multi-responsive chitosan biomaterials doped with biocompatible ammonium ionic liquids. ACS Sustain. Chem. Eng. 2013, 1, 1480-1492. [CrossRef]

113. Chantereau, G.; Sharma, M.; Abednejad, A.; Vilela, C.; Costa, E.M.; Veiga, M.; Antunes, F.; Pintado, M.M.; Sèbe, G.; Coma, V.; et al. Bacterial nanocellulose membranes loaded with vitamin B-based ionic liquids for dermal care applications. J. Mol. Liq. 2020, 302, 112547. [CrossRef]

114. Kuddushi, M.; Nehal, P. Temperature-Responsive Low Molecular Weight Ionic Liquid Based Gelator: Temperature-Responsive Low Molecular Weight Ionic Liquid Based Gelator: An Approach to Fabricate an Anti-Cancer Drug-Loaded Hybrid Ionogel. Chem Syst. Chem 2020, 2, e1900053. [CrossRef]

115. Zhang, J.; Jiang, X.; Wen, X.; Xu, Q.; Zeng, H.; Zhao, Y.; Liu, M.; Wang, Z. Bio-responsive smart polymers and biomedical applications. J. Phys. Mater. 2019, 2, 032004. [CrossRef]

116. Green, O.; Grubjesic, S.; Lee, S.; Firestone, M.A. The design of polymeric ionic liquids for the preparation of functional materials. Polym. Rev. 2009, 49, 339-360. [CrossRef]

117. Cui, W.; Lu, X.; Cui, K.; Niu, L.; Wei, Y.; Lu, Q. Dual-responsive controlled drug delivery based on ionically assembled nanoparticles. Langmuir 2012, 28, 9413-9420. [CrossRef] [PubMed] 